Article

\title{
Geochemical Behavior of Different Chemical Elements during Weathering of the Basalts in Changbai Mountain, Northeast China
}

\author{
Tian Lan ${ }^{1}$, Libo Hao ${ }^{1}$, Jilong Lu ${ }^{1, *}$, , Yechang Yin ${ }^{2}$, Xiaoqing Chen ${ }^{3}$, Yuchao Fan ${ }^{1}$, Wei Zhao ${ }^{1}$ and Yaru Hou ${ }^{1}$ \\ 1 College of Geo-Exploration Science and Technology, Jilin University, Changchun 130026, China; \\ lantian19@mails.jlu.edu.cn (T.L.); haolb@jlu.edu.cn (L.H.); fanyc19@mails.jlu.edu.cn (Y.F.); \\ weizhao19@mails.jlu.edu.cn (W.Z.); houyr20@mails.jlu.edu.cn (Y.H.) \\ 2 Institute of Mining Technology, Liaoning Technical University, Fuxin 123000, China; \\ yinyechang_lntu@163.com \\ 3 College of Earth Science, Jilin University, Changchun 130016, China; xqchen18@mails.jlu.edu.cn \\ * Correspondence: lujl@jlu.edu.cn
}

Citation: Lan, T.; Hao, L.; Lu, J.; Yin, Y.; Chen, X.; Fan, Y.; Zhao, W.; Hou, Y. Geochemical Behavior of Different Chemical Elements during Weathering of the Basalts in Changbai Mountain, Northeast China. Sustainability 2021, 13, 12796. https://doi.org/10.3390/su132212796

Academic Editor: Vinicio Manzi

Received: 13 October 2021

Accepted: 17 November 2021

Published: 19 November 2021

Publisher's Note: MDPI stays neutral with regard to jurisdictional claims in published maps and institutional affiliations.

Copyright: (c) 2021 by the authors. Licensee MDPI, Basel, Switzerland. This article is an open access article distributed under the terms and conditions of the Creative Commons Attribution (CC BY) license (https:/ / creativecommons.org/licenses/by/ $4.0 /)$.

\begin{abstract}
Rock weathering is the main source of element geochemical cycle, which has a very important impact on the environment. Three well-developed basalt weathering profiles in Changbai Mountain area are selected in this study, and the samples of parent rock, parent material layer, sedimentary layer, and leaching layer are systematically collected. The systematic study showed that the basalt in the study area experienced moderate chemical weathering under warm and humid climate conditions, with leaching of some major elements such as silicon and aluminum. The distribution of the rare earth elements (REE) in the weathering products recalls that of an alkali-basalt, with an evident fractionation between light- and heavy-REE. Such a feature is therefore referable to the parent volcanic rock, although with some degree of leaching.
\end{abstract}

Keywords: basalt; weathering; geochemical behavior of elements; Changbai Mountain; northeast China

\section{Introduction}

The geochemical behavior of elements during rock weathering has a great impact on the chemical composition, formation, and evolution of soil and sediments. It has become an important link connecting land and ocean, rivers and lakes, and paleoclimate and paleoenvironment. Weathering may be regarded as the premise and foundation of soil occurrence, and soil formation may be regarded as the continuation and deepening of weathering. In the process of weathering and soil formation, the factors affecting the distribution characteristics of soil elements mainly include parent rock and parent material, climatic conditions, hydrochemical properties, and redox conditions [1]. As known, basalt has a higher weathering rate than many other volcanic rocks. At present, basalt weathering research mainly focuses on mineralization, behavior of major and trace elements, and isotopic behavior caused by weathering in tropical climate (Hainan Island) and subtropical climate (Emeishan basalt) [2-5]. After desilication and aluminum weathering, basalt forms aluminum weathering crust, and gradually develops into iron-rich soil and iron aluminum soil. However, the subsequent enrichment of transition metal elements (such as $\mathrm{Cr}, \mathrm{Ni}$, $\mathrm{V}, \mathrm{Co}, \mathrm{Mn}$, and $\mathrm{Zn}$ ) may lead to significant environmental risks [6-9]. Alkali metals and alkaline earth metals with active chemical properties such as $\mathrm{Na}, \mathrm{Ca}$, and $\mathrm{Mg}$ are easy to lose during rock weathering. However, elements with stable chemical properties such as $\mathrm{Th}, \mathrm{U}, \mathrm{Zr}, \mathrm{Nb}, \mathrm{Y}$, and rare earth elements are not easy to migrate [10-19]. In addition, relative behaviors of immobile elements during weathering are usually stable from rock to its weathered products. The stability of these relative behaviors is similar to the genetic inheritance in biology [20]. 
The research of Changbai Mountain basalt mainly focuses on the genesis [21], rock geochemistry, age [22,23], and evolution process of basalt [24]. At present, Changbai Mountain has become one of the important natural resource reserves in China. This study comprehensively analyzes a variety of weathering indexes with the help of geochemical methods and systematically discusses the weathering process of basalt in Changbai Mountain area. This study addresses the behavior of elements in the chemical weathering process of basalt in the study area, hence, revealing the impact of traces element enrichment and leaching on the surface soil.

\section{Study Samples and Methods}

\subsection{Geological Setting and Location of Samples}

Changbai Mountain is located in the east of the Central Asian orogenic belt. The region experienced the evolution of Paleo Asian Ocean tectonic system in Paleozoic, resulting in the final closure of microlandmass (including Erguna block, Xing'an block, Songnen zhangguangcailing block, Jiamusi block, and Xingkai block) and Paleozoic-early Mesozoic Paleoasian Ocean [25,26] (Figure 1). Cenozoic is the main active period of basalt magma. Since Cenozoic, a large number of basaltic volcanic rocks (trachyte basalt, trachyte basaltic andesite, tholeiite, and basaltic andesite) have been exposed in eastern China [27,28].

The study area is located in the east of Jilin Province, covering Baishan and Yanbian (Figure 1). The ground is high in the southeast and low in the northwest, with an obvious erosion and cutting effect. The study area has a mid-temperate, continental, humid monsoon climate, with an annual average temperature of $3-5^{\circ} \mathrm{C}$, an average temperature of $-18{ }^{\circ} \mathrm{C}$ in January, and an average temperature of $23^{\circ} \mathrm{C}$ in July. The annual precipitation is mainly concentrated from June to August (about $1100 \mathrm{~mm}$ ), accounting for about $60 \%$ of the total annual precipitation. The soil types in the study area mainly include brown coniferous forest soil, dark brown soil, and albic soil. In the vertical zone of Changbai Mountain, the soil of brown coniferous forest is scattered under the coniferous forest with an altitude of 1100-1800 m. Dark brown soil is mainly distributed in the East and southeast of Jilin Province, with an altitude of 500-1200 m. In addition, albic soil is widely distributed in mountainous, semimountainous, and valley terraces in the east and southeast of Jilin Province.

The study samples were taken from three well-developed basalt weathering profiles in the upper reaches of the Songhua River. The location of the soil profile is shown in Table 1. After discarding the humus layer, the weathering profile is divided into four layers from top to bottom, with an average depth of $1.5 \mathrm{~m}$. The different horizons in Figure 2 are called horizons A, B, C, and R. Layer A is the leaching layer: sampling depth is about $5 \sim 30 \mathrm{~cm}$; soil in this layer is dark and rich in organic matters. Layer B is the sedimentary layer: sampling depth is about $30 \sim 70 \mathrm{~cm}$; soil in this layer is brown and rich in organic matters and microconglomerate. Layer $C$ is the parent material layer: sampling depth is about 70 120 cm; soil in this layer is light brown, containing massive weathering rocks and residual debris. Layer $\mathrm{R}$ is parent rock: grey vesiculate basalt of this layer was collected from depths of 120 150 cm.

Table 1. Sampling locations of the studied soil profiles.

\begin{tabular}{ccccc}
\hline \multirow{2}{*}{ Soil Profile } & \multirow{2}{*}{$\begin{array}{c}\text { Parent Rocks } \\
\text { Lithologies }\end{array}$} & Latitude & Longitude & \multirow{2}{*}{$\begin{array}{c}\text { Elevations (m } \\
\text { above Sea Level) }\end{array}$} \\
\cline { 3 - 4 } & & vecations & 547 \\
JLP1 & vesiculate basalt & $42^{\circ} 24^{\prime} 07^{\prime \prime}$ & $126^{\circ} 47^{\prime} 03^{\prime \prime}$ & 733 \\
JLP2 & vesiculate basalt & $42^{\circ} 30^{\prime} 35^{\prime \prime}$ & $127^{\circ} 49^{\prime} 23^{\prime \prime}$ & 1107 \\
JLP3 & vesiculate basalt & $42^{\circ} 11^{\prime} 44^{\prime \prime}$ & $128^{\circ} 10^{\prime} 32^{\prime \prime}$ & \\
\hline
\end{tabular}




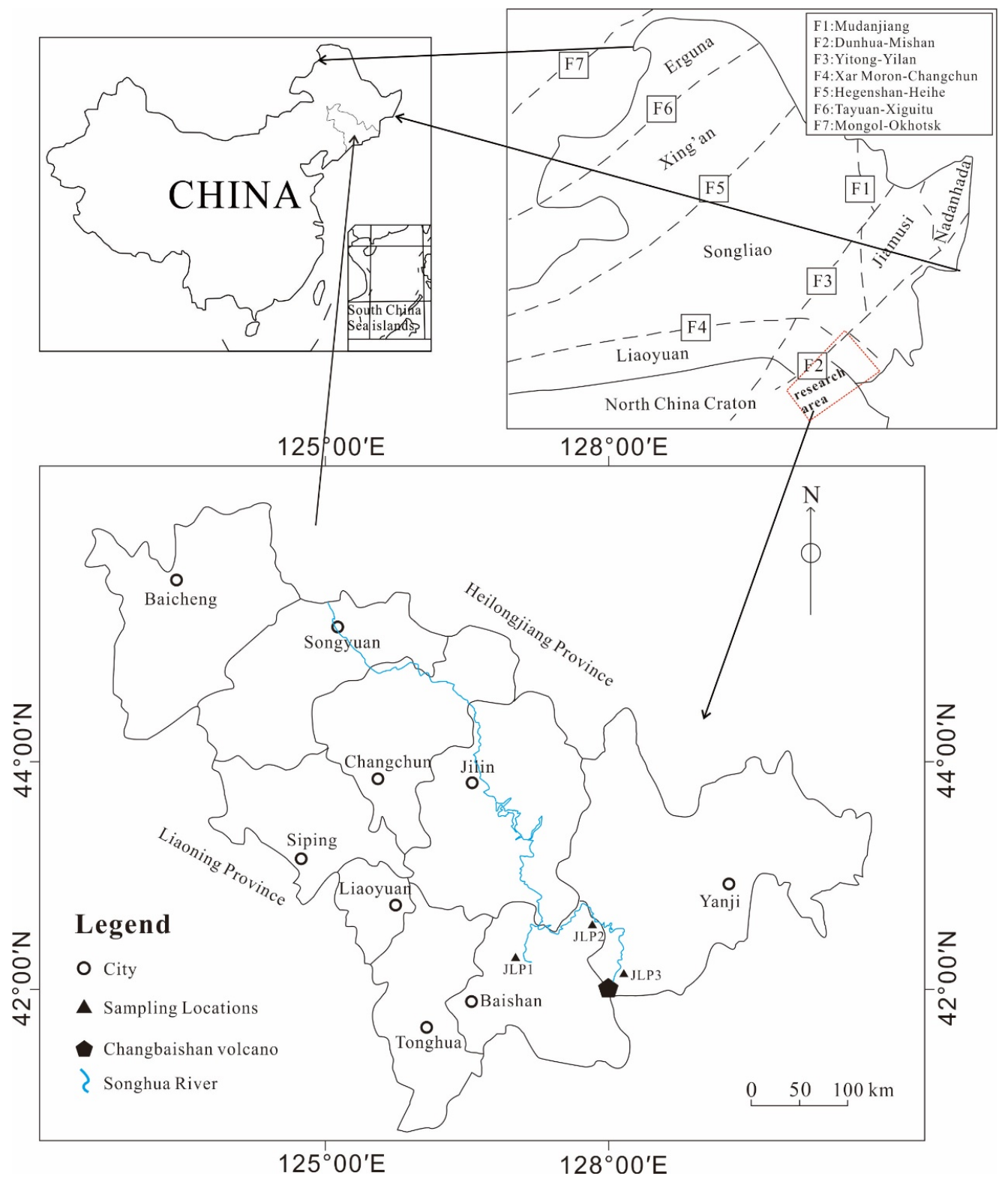

Figure 1. Geographic and geotectonic setting of the study area and location of the soil profiles [29].

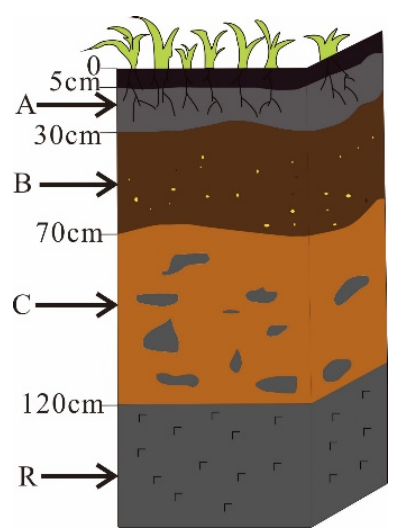

Figure 2. Weathering profile sketch. 


\subsection{Materials and Methods}

As a first step, soil samples were placed in a glass tray after removing foreign matters such as branches, rods, and leaves, and fully mixed. The sample was crushed to less than 200 mesh by the crusher and sieved. The sieved sample was put into the dryer for cooling. The loss on ignition was determined by the mass loss after calcination at $1000{ }^{\circ} \mathrm{C}$ in muffle furnace. According to HJ780-2015 standard, the contents of $\mathrm{SiO}_{2}, \mathrm{Al}_{2} \mathrm{O}_{3}, \mathrm{MgO}, \mathrm{Fe}_{2} \mathrm{O}_{3}$, $\mathrm{CaO}, \mathrm{Na}_{2} \mathrm{O}, \mathrm{K}_{2} \mathrm{O}, \mathrm{P}_{2} \mathrm{O}_{5}, \mathrm{TiO}_{2}$, and $\mathrm{MnO}$ were determined by powder compression X-ray fluorescence spectrometry (EDX6000b). According to GB/T 14506-2010, the contents of $\mathrm{La}, \mathrm{Ce}, \mathrm{Pr}, \mathrm{Nd}, \mathrm{Sm}, \mathrm{Eu}, \mathrm{Gd}, \mathrm{Tb}, \mathrm{Dy}, \mathrm{Ho}, \mathrm{Er}, \mathrm{Tm}, \mathrm{Yb}$, and Lu were determined by ICP-MS (NEXION350d, PerkinElmer) and sodium peroxide molten samples. In addition, lead, rubidium, strontium, barium, zirconium, niobium, thorium, yttrium, and uranium were determined by closed acid digestion ICP-MS. According to HJ680-2013 standard, arsenic and mercury were determined by potassium borohydride reduction atomic fluorescence spectrometry in aqua regia solution.

Aforementioned analytical methods fulfil the requirements of the Chinese geological and mineral standard DZ/T0011-2015.

\section{Results}

The mass fraction and composition of main elements are the most commonly used indicators in the study of weathering. The order of average concentration of the soil profile samples is $\mathrm{SiO}_{2}>\mathrm{Al}_{2} \mathrm{O}_{3}>\mathrm{Fe}_{2} \mathrm{O}_{3}>\mathrm{K}_{2} \mathrm{O}>\mathrm{Na}_{2} \mathrm{O}>\mathrm{MgO}>\mathrm{TiO}_{2}>\mathrm{CaO}>\mathrm{P}_{2} \mathrm{O}_{5}>\mathrm{MnO}$ (Table 2). The $\mathrm{SiO}_{2}, \mathrm{Al}_{2} \mathrm{O}_{3}$, and $\mathrm{Fe}_{2} \mathrm{O}_{3}$ are the three elements with the highest content in all samples (the sum exceeds $80 \%$ ).

Table 2. Content of major elements $(\mathrm{wt} \%)$ of the soil profile samples. L.O.I $=$ loss of ignition; CIA index $=\left(\mathrm{Al}_{2} \mathrm{O}_{3} /\left(\mathrm{Al}_{2} \mathrm{O}_{3}+\right.\right.$ $\left.\left.\mathrm{CaO}^{*}+\mathrm{K}_{2} \mathrm{O}+\mathrm{Na}_{2} \mathrm{O}\right)\right) \times 100 ;$ Parker index $=\left(2 \mathrm{Na}_{2} \mathrm{O} / 0.35+\mathrm{MgO} / 0.9+2 \mathrm{~K}_{2} \mathrm{O} / 0.25+\mathrm{CaO} / 0.7\right) \times 100$.

\begin{tabular}{|c|c|c|c|c|c|c|c|c|c|c|c|c|c|}
\hline Sample & $\mathrm{SiO}_{2}$ & $\mathrm{Al}_{2} \mathrm{O}_{3}$ & $\mathrm{MgO}$ & $\mathrm{TFe}_{2} \mathrm{O}_{3}$ & $\mathrm{CaO}$ & $\mathrm{Na}_{2} \mathrm{O}$ & $\mathrm{K}_{2} \mathrm{O}$ & $\mathrm{P}_{2} \mathrm{O}_{5}$ & $\mathrm{TiO}_{2}$ & $\mathrm{MnO}$ & L.O.I. & CIA & Parker \\
\hline JLP1-A & 68.10 & 13.76 & 1.26 & 5.94 & 1.10 & 1.90 & 2.20 & 0.23 & 1.07 & 0.22 & 1.14 & 66.42 & 42.48 \\
\hline JLP1-B & 64.46 & 15.30 & 1.39 & 6.90 & 0.85 & 1.56 & 2.32 & 0.31 & 1.09 & 0.11 & 0.37 & 72.23 & 40.08 \\
\hline JLP1-C & 53.19 & 19.33 & 1.38 & 11.84 & 1.17 & 1.24 & 1.78 & 0.71 & 1.65 & 0.08 & 0.26 & 81.47 & 33.33 \\
\hline JLP1-R & 54.50 & 19.42 & 3.07 & 9.04 & 6.29 & 3.44 & 2.45 & 0.95 & 1.79 & 0.13 & 1.90 & 52.62 & 77.02 \\
\hline JLP2-A & 69.13 & 13.92 & 1.11 & 5.66 & 0.73 & 1.75 & 2.59 & 0.18 & 1.16 & 0.18 & 0.62 & 67.90 & 43.05 \\
\hline JLP2-B & 67.39 & 15.60 & 1.22 & 5.84 & 0.61 & 1.52 & 2.60 & 0.17 & 1.08 & 0.10 & 0.40 & 72.16 & 41.01 \\
\hline JLP2-C & 56.12 & 21.24 & 1.06 & 9.30 & 0.99 & 1.64 & 2.85 & 0.73 & 1.81 & 0.12 & 0.35 & 78.44 & 44.77 \\
\hline JLP2-R & 51.77 & 19.20 & 4.12 & 10.05 & 5.98 & 3.15 & 2.48 & 0.93 & 2.06 & 0.17 & 0.88 & 53.74 & 76.71 \\
\hline JLP3-A & 68.83 & 14.20 & 1.27 & 4.69 & 1.06 & 1.69 & 2.45 & 0.17 & 0.77 & 0.09 & 1.58 & 67.13 & 42.59 \\
\hline JLP3-B & 67.14 & 15.32 & 1.39 & 5.06 & 0.96 & 1.48 & 2.49 & 0.16 & 0.79 & 0.07 & 0.59 & 70.23 & 41.07 \\
\hline JLP3-C & 63.07 & 17.74 & 1.59 & 6.28 & 1.25 & 1.68 & 2.26 & 0.24 & 0.84 & 0.06 & 0.30 & 71.97 & 42.25 \\
\hline JLP3-R & 53.23 & 15.96 & 2.31 & 7.62 & 3.38 & 3.44 & 2.41 & 0.38 & 0.96 & 0.10 & 2.04 & 54.16 & 67.16 \\
\hline $\begin{array}{l}\text { Average } \\
(\mathrm{A}-\mathrm{C})\end{array}$ & 64.16 & 16.27 & 1.30 & 6.83 & 0.97 & 1.61 & 2.39 & 0.32 & 1.14 & 0.11 & 0.62 & & \\
\hline
\end{tabular}

The total content of rare earth elements (REE) in the samples in the study area is relatively high (Tables 3 and 4). However, $\mathrm{Yb}$ and $\mathrm{Lu}$ are lower than the background value, the content of rare earth elements in other samples is 1-2.5 times higher than the background value; further, except $\mathrm{Ho}, \mathrm{Er}, \mathrm{Tm}, \mathrm{Yb}$, and $\mathrm{Lu}$, rare earth elements in other samples are lost layer-by-layer from parent rock to leaching layer during weathering, and the loss order is LREE > HREE.

The average value of $\mathrm{Sr}, \mathrm{Ba}$, and $\mathrm{Nb}$ in the parent rock is higher than that of the setting, and the content of other value is lower than that of the setting (Table 5). The average value of $\mathrm{Ba}, \mathrm{Nb}$, and $\mathrm{Y}$ in the parent material layer is higher than that of the setting, and the value of other elements are lower than that of the setting. The average value of $\mathrm{Rb}, \mathrm{Ba}$, and $\mathrm{Y}$ in the sedimentary layer is higher than that of the setting, and the value of other elements are lower than that of the setting. The average value of $\mathrm{Pb}$ and $\mathrm{Ba}$ in the leaching layer is higher than that of the setting, and the value of other elements are lower than that of the setting. 
Table 3. Content (ppm) and characteristic parameters of rare earth elements in the profile samples. Background values of soil elements in China [30,31].

\begin{tabular}{|c|c|c|c|c|c|c|c|c|c|c|c|c|c|c|}
\hline Sample & $\mathrm{La}$ & $\mathrm{Ce}$ & Pr & $\mathrm{Nd}$ & $\mathrm{Sm}$ & Eu & $\mathrm{Gd}$ & $\mathrm{Tb}$ & Dy & Ho & Er & $\mathrm{Tm}$ & $\mathrm{Yb}$ & Lu \\
\hline JLP1-A & 33.88 & 77.76 & 7.34 & 27.95 & 5.13 & 1.15 & 4.40 & 0.75 & 4.19 & 0.84 & 2.26 & 0.41 & 2.62 & 0.41 \\
\hline JLP1-B & 40.74 & 78.32 & 9.13 & 35.18 & 6.79 & 1.52 & 5.52 & 1.02 & 5.46 & 1.06 & 2.98 & 0.51 & 3.31 & 0.50 \\
\hline JLP1-C & 55.79 & 102.61 & 11.49 & 44.68 & 8.56 & 2.34 & 7.10 & 1.17 & 5.94 & 1.08 & 2.83 & 0.47 & 2.88 & 0.43 \\
\hline JLP1-R & 54.89 & 99.09 & 11.59 & 46.8 & 8.44 & 2.68 & 7.47 & 1.00 & 4.73 & 0.75 & 1.86 & 0.24 & 1.39 & 0.19 \\
\hline JLP2-A & 46.35 & 90.87 & 9.94 & 35.24 & 6.22 & 1.08 & 5.35 & 0.86 & 4.94 & 0.98 & 2.84 & 0.48 & 2.96 & 0.46 \\
\hline JLP2-B & 58.82 & 113.98 & 14.57 & 56.05 & 9.89 & 2.34 & 7.82 & 1.15 & 5.84 & 1.08 & 2.86 & 0.46 & 2.68 & 0.41 \\
\hline JLP2-C & 65.11 & 120.39 & 16.59 & 64.09 & 10.79 & 2.58 & 8.64 & 1.17 & 6.02 & 1.09 & 2.94 & 0.46 & 2.65 & 0.40 \\
\hline JLP2-R & 60.32 & 108.43 & 12.27 & 47.48 & 8.16 & 2.78 & 7.74 & 1.08 & 5.70 & 1.01 & 2.74 & 0.38 & 2.35 & 0.35 \\
\hline JLP3-A & 52.84 & 105.47 & 12.33 & 48.10 & 8.48 & 2.23 & 6.49 & 1.03 & 5.24 & 0.97 & 2.51 & 0.41 & 2.60 & 0.38 \\
\hline JLP3-B & 50.08 & 124.32 & 9.99 & 36.15 & 6.42 & 1.80 & 5.62 & 0.81 & 4.22 & 0.77 & 2.03 & 0.33 & 1.93 & 0.30 \\
\hline JLP3-C & 39.37 & 73.12 & 8.73 & 34.17 & 6.34 & 1.81 & 5.30 & 0.82 & 4.28 & 0.80 & 2.09 & 0.33 & 1.99 & 0.31 \\
\hline JLP3-R & 52.38 & 110.44 & 13.95 & 58.40 & 10.09 & 2.90 & 8.61 & 1.18 & 5.90 & 1.02 & 2.80 & 0.38 & 2.32 & 0.33 \\
\hline Background & 40.00 & 68.00 & 7.20 & 26.00 & 5.20 & 1.00 & 4.60 & 0.63 & 4.10 & 0.87 & 2.50 & 0.37 & 2.40 & 0.36 \\
\hline
\end{tabular}

Table 4. Content (ppm) and characteristic parameters of rare earth elements in the profile samples. Background values of soil elements in China [30,31].

\begin{tabular}{|c|c|c|c|c|c|c|c|c|}
\hline Sample & $\Sigma \mathrm{REE}$ & $\Sigma$ LREE & $\Sigma$ HREE & LREE/HREE & $\delta \mathrm{Eu}$ & $\delta \mathrm{Ce}$ & $(\mathrm{La} / \mathrm{Sm})_{\mathrm{N}}$ & $(\mathrm{La} / \mathrm{Yb})_{\mathrm{N}}$ \\
\hline JLP1-A & 169.09 & 153.21 & 15.88 & 9.65 & 0.72 & 1.14 & 4.15 & 8.72 \\
\hline JLP1-B & 192.04 & 171.68 & 20.36 & 8.43 & 0.74 & 0.94 & 3.77 & 8.30 \\
\hline JLP1-C & 247.37 & 225.47 & 21.90 & 10.30 & 0.89 & 0.93 & 4.10 & 13.06 \\
\hline JLP1-R & 241.12 & 223.49 & 17.63 & 12.68 & 1.01 & 0.90 & 4.09 & 26.62 \\
\hline JLP2-A & 208.62 & 189.75 & 18.87 & 10.06 & 0.56 & 0.97 & 4.69 & 10.57 \\
\hline JLP2-B & 277.93 & 255.63 & 22.30 & 11.46 & 0.79 & 0.91 & 3.74 & 14.79 \\
\hline JLP2-C & 302.91 & 279.54 & 23.37 & 11.96 & 0.79 & 0.86 & 3.80 & 16.56 \\
\hline JLP2-R & 260.79 & 239.44 & 21.35 & 11.21 & 1.05 & 0.91 & 4.65 & 17.31 \\
\hline JLP3-A & 249.08 & 229.45 & 19.63 & 11.69 & 0.89 & 0.96 & 3.92 & 13.70 \\
\hline JLP3-B & 244.77 & 228.76 & 16.01 & 14.29 & 0.90 & 1.26 & 4.91 & 17.49 \\
\hline JLP3-C & 179.46 & 163.54 & 15.92 & 10.27 & 0.93 & 0.91 & 3.91 & 13.34 \\
\hline JLP3-R & 270.70 & 248.16 & 22.54 & 11.01 & 0.93 & 0.96 & 3.27 & 15.22 \\
\hline Background & 163.23 & 147.40 & 15.83 & 9.31 & & & & \\
\hline
\end{tabular}

Table 5. Content of trace elements (ppm) in the profile samples. Background values of soil elements in China [30,31].

\begin{tabular}{cccccccccc}
\hline Sample & $\mathbf{P b}$ & $\mathbf{R b}$ & $\mathbf{S r}$ & $\mathbf{B a}$ & $\mathbf{Z r}$ & $\mathbf{N b}$ & $\mathbf{T h}$ & $\mathbf{Y}$ & $\mathbf{U}$ \\
\hline JLP1-A & 29.30 & 106.00 & 172.00 & 625.00 & 69.20 & 20.10 & 12.00 & 22.00 & 2.38 \\
JLP1-B & 28.60 & 114.00 & 157.00 & 597.00 & 79.00 & 22.00 & 13.70 & 28.60 & 3.03 \\
JLP1-C & 21.00 & 26.30 & 117.00 & 759.00 & 132.00 & 44.90 & 11.50 & 36.50 & 2.46 \\
JLP1-R & 9.70 & 10.70 & 720.00 & 907.00 & 106.00 & 60.80 & 7.24 & 19.00 & 1.51 \\
JLP2-A & 36.80 & 104.00 & 156.00 & 680.00 & 76.40 & 23.60 & 12.70 & 21.40 & 2.51 \\
JLP2-B & 27.80 & 115.00 & 134.00 & 680.00 & 83.00 & 22.80 & 13.30 & 22.60 \\
JLP2-C & 22.90 & 63.00 & 164.00 & 694.00 & 123.00 & 38.40 & 13.30 & 29.20 & 2.80 \\
JLP2-R & 9.30 & 51.20 & 525.00 & 1465.00 & 127.00 & 43.40 & 5.24 & 14.80 & 1.27 \\
JLP3-A & 28.50 & 104.00 & 155.00 & 838.00 & 71.50 & 24.20 & 9.85 & 21.70 & 2.00 \\
JLP3-B & 29.20 & 115.00 & 153.00 & 837.00 & 75.20 & 29.40 & 9.11 & 19.30 & 1.82 \\
JLP3-C & 23.80 & 112.00 & 150.00 & 890.00 & 82.90 & 35.90 & 8.73 & 16.00 & 1.43 \\
JLP3-R & 14.10 & 78.70 & 254.00 & 1066.00 & 99.80 & 26.70 & 5.12 & 12.60 & 0.82 \\
Background & 26.00 & 111.00 & 166.00 & 469.00 & 258.00 & 34.00 & 14.00 & 23.00 \\
\hline
\end{tabular}

\section{Discussion}

\subsection{Behavior of the Major Elements}

With the formation of new mineral assemblage after rock fracture, the main elements of basalt in the study area experienced the process of desalting basement-enrichment of $\mathrm{SiO}_{2}$ and $\mathrm{Al}_{2} \mathrm{O}_{3}$ from parent rock to parent material layer in the early stage of weathering (except silicon and aluminum, other main elements were leached in varying degrees; 
Table 2; Figure 3). In the profiles JLP2, the concentrations of $\mathrm{SiO}_{2}$ and $\mathrm{Al}_{2} \mathrm{O}_{3}$ in parent rocks are $51.77 \%$ and $19.20 \%$, while they are $56.12 \%$ and $21.24 \%$ in the parent material layer. In the profiles JLP3, the concentrations of $\mathrm{SiO}_{2}$ and $\mathrm{Al}_{2} \mathrm{O}_{3}$ in parent rocks are $53.23 \%$ and $15.96 \%$, while they are $63.07 \%$ and $17.74 \%$ in parent material layer. From the parent material layer to the sedimentary layer, weathering experienced silicon enrichment and dealumination (except silicon, other main elements were leached, in which aluminum leaching was strong). In the highest stage of weathering, except manganese, the behavior of other elements from sedimentary layer to leaching layer tends to be stable. Due to acid leaching, Mn is relatively enriched in the leaching layer. Among the three groups of basalt weathering profiles, the change trend of main elements in JLP3 profile is slower than that in the other two groups, suggesting that higher altitude will lead to weaker weathering degree.

Chemical weathering index is usually used to describe the behavior of elements during weathering. Existing studies have shown that there are more than 30 different chemical weathering indexes, including those for the study of rocks and their weathering products [32-35]. Generally, chemical weathering index can be divided into two categories: normalized index and non-normalized index. Due to the lack of chemical analyses on bedrock, in the study case, the application of normalization indexes is not possible. The widely used nonstandardized indexes include Parker weathering index (WIP) [36], chemical alteration index (CIA) [37], chemical weathering index (CIW) [38], Coleman weathering index (WIC) [39], and plagioclase alteration index (PIA) [40]. Due to the lack of $\mathrm{CO}_{2}$ content data in this study, $\mathrm{Cao}^{*}$ ( $\mathrm{CaO}$ in silicate) is calculated in the absence of $\mathrm{CO}_{2}$ content according to the correction method of McLennan [41]. Parker and CIA in the non-normalized index are used to characterize the element behavior during the weathering of Changbai Mountain basalt.

From the results of major element analysis (Table 1), it can be seen that $\mathrm{SiO}_{2}$ is enriched in the weathering process, while $\mathrm{K}_{2} \mathrm{O}, \mathrm{Na}_{2} \mathrm{O}$, and $\mathrm{CaO}$ are obviously leached, which is consistent with the characteristics that $\mathrm{SiO}_{2}$ tends to be active in the rock weathering process. Its total leaching rate is usually very small, and alkali metals and alkaline earth metals will be significantly lost. Therefore, the study area is more in line with the application conditions of Parker index.

This is example 1 of an equation:

$$
\text { Parker index }=\left(2 \mathrm{Na}_{2} \mathrm{O} / 0.35+\mathrm{MgO} / 0.9+2 \mathrm{~K}_{2} \mathrm{O} / 0.25+\mathrm{CaO} / 0.7\right) \times 100 \text {. }
$$

Generally, the Parker index reflects the weathering degree, and the corresponding is inversely correlated with the weathering degree. The index of parent material layer is 33.33-44.77, with an average of 40.12; the sedimentary layer is $40.08-41.07$, with an average of 40.72; the leaching layer is 42.48-43.05, with an average of 42.07 (Table 2).

Nesbitt and Young proposed the chemical alteration index (CIA) for the first time. According to the early Proterozoic sediments of Huron supergroup in the north of Huron, they reconstructed the paleoclimate [37], which has been widely used at present. According to Nesbitt theory, when the CIA index is between 50-65, it means cold and dry climate conditions, and the weathering in the source area belongs to low chemical weathering degree; when the CIA index is between 65 and 85, the provenance area is in warm and humid climate, and the weathering is of medium chemical weathering degree; when the CIA index is between 85 and 100, the weathering in the provenance area belongs to tropical or subtropical humid and hot climate conditions, and the weathering belongs to strong chemical weathering. The calculation method is as follows:

$$
\mathrm{CIA}=\left[\mathrm{Al}_{2} \mathrm{O}_{3} /\left(\mathrm{Al}_{2} \mathrm{O}_{3}+\mathrm{CaO}^{*}+\mathrm{K}_{2} \mathrm{O}+\mathrm{Na}_{2} \mathrm{O}\right)\right] \times 100
$$

The oxide content is determined by mole fraction. Cao* refers to Cao in silicate-that is, the mole fraction of Cao removed from rock by chemical deposition. The calculation method is as follows: 


$$
\mathrm{CaO}^{*}=\mathrm{CaO}-\left(10 / 3 \times \mathrm{P}_{2} \mathrm{O}_{5}\right)
$$
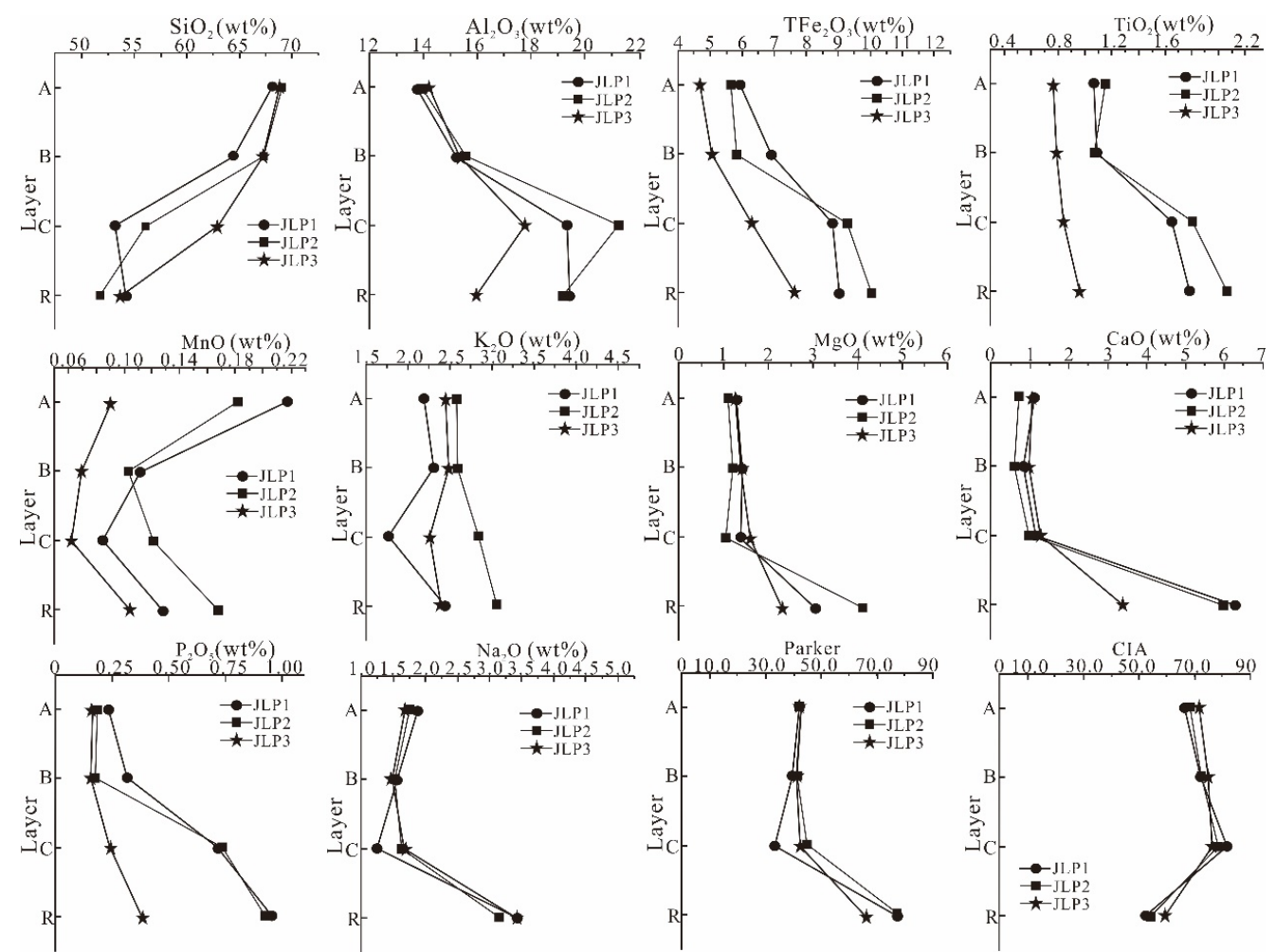

Figure 3. Content changes of the major elements in the soil profiles.

The CIA index of parent material layer ranged from 71.49 to 81.48 , with an average of 77.29; the CIA index of sedimentary layer ranged from 70.23 to 72.23 , with an average of 71.54; the CIA index of the leaching layer ranged from 66.42 to 67.90 , with an average of 67.15 (Table 2). Most of the three sections have the characteristics of increasing CIA index from leaching layer to parent material layer. According to the above classification, the CIA index of the parent material layer, sedimentary layer, and leaching layer ranges from 65 to 85 , indicating that the climatic conditions in the area are warm and humid, belonging to moderate chemical weathering.

Compared with Changbai Mountain basalt profile, the CIA index of soil samples in Hainan basalt weathering profile is 93.98-97.78, indicating that Hainan basalt is strongly chemically weathered with the enrichment of desilication, aluminum, and iron. Under extreme environmental conditions, the influence of parent rock on the development strength of weathered crust is weakened, and even covered by climatic conditions, resulting in the formation of weathered crust in the stage of medium lateritic or even strong lateritic [2,42].

According to the above weathering index calculation, the parent rock weathering degree of the three sections is low. Therefore, the element mobility $M=100$ can be determined $\times$ (The enrichment or leaching rates of elements in different profiles are calculated by RI-RP/RP) formula. In the same section, RI represents the $X$ element content in weathered samples, and RP represents the $X$ element content of parent rock samples. In the parent material layer, sedimentary layer, and leaching layer of the three sections, the cumulative mobility of $\mathrm{SiO}_{2}$ is the highest (Figure 4), indicating its enrichment characteristics in the weathering process, while other elements are leached in the weathering process. The average values of Cao element mobility in layers A, B, and C are $-0.79,-0.83$, and -0.74 , respectively, indicating that Cao is most seriously lost during weathering (Table 6; Figure 3). $\mathrm{K}_{2} \mathrm{O}$ mobility fluctuates the least, and the average value of the three profiles is 0 , 
indicating that its mobility is the smallest and most stable in the weathering process, and the stability of $\mathrm{Al}_{2} \mathrm{O}_{3}$ and $\mathrm{TiO}_{2}$ is second only to $\mathrm{K}_{2} \mathrm{O}$.

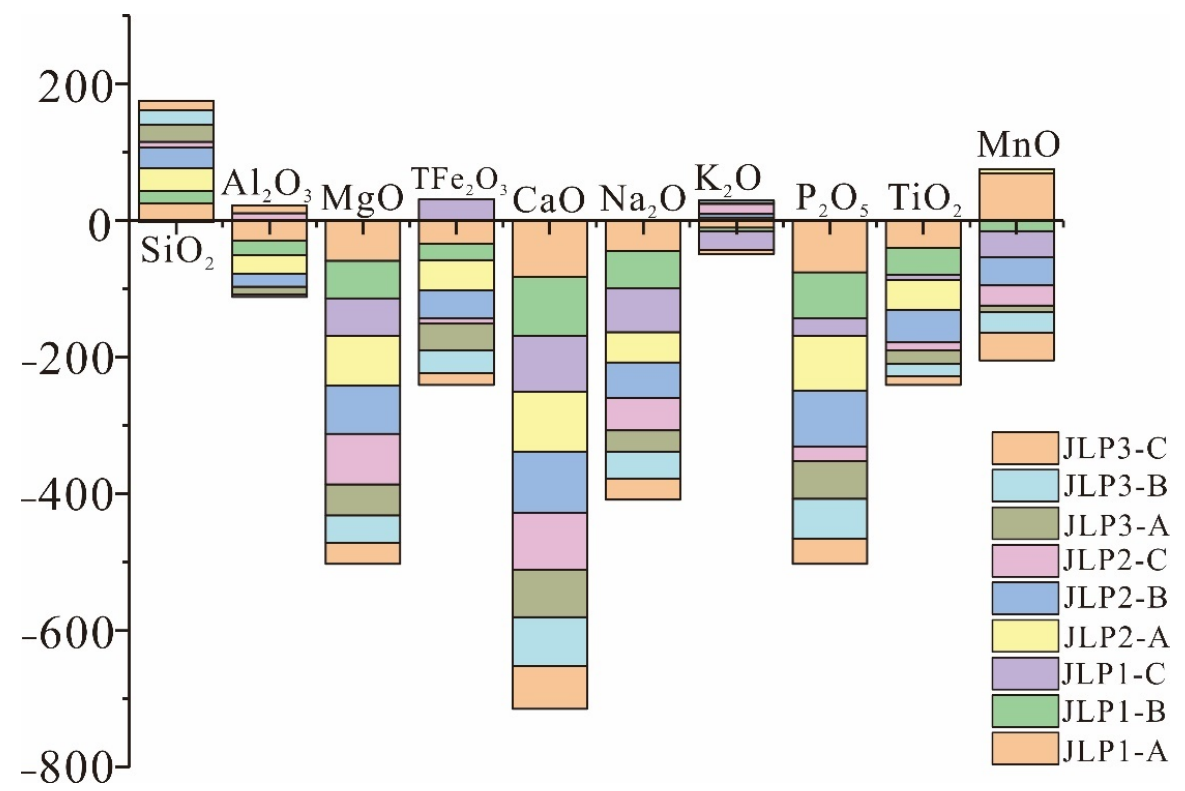

Figure 4. Stacking diagram of mobility of the major elements.

Table 6. Mobility of the major elements.

\begin{tabular}{ccccccccccc}
\hline Sample & $\mathbf{S i O}_{2}$ & $\mathbf{A l}_{\mathbf{2}} \mathbf{O}_{\mathbf{3}}$ & $\mathbf{M g O}$ & $\mathbf{T F e}_{\mathbf{2}} \mathbf{O}_{\mathbf{3}}$ & $\mathbf{C a O}$ & $\mathbf{N a}_{\mathbf{2}} \mathbf{O}$ & $\mathbf{K}_{\mathbf{2}} \mathbf{O}$ & $\mathbf{P}_{2} \mathbf{O}_{5}$ & $\mathbf{T i O}_{2}$ & $\mathbf{M n O}$ \\
\hline JLP1-A & 0.39 & -0.21 & -0.54 & -0.27 & -0.81 & -0.38 & 0.00 & -0.73 & -0.33 & 0.88 \\
JLP1-B & 0.25 & -0.17 & -0.52 & -0.19 & -0.86 & -0.52 & 0.00 & -0.66 & -0.36 & -0.11 \\
JLP1-C & 0.34 & 0.37 & -0.38 & 0.80 & -0.74 & -0.50 & 0.00 & 0.03 & 0.27 & -0.15 \\
JLP2-A & 0.28 & -0.31 & -0.74 & -0.46 & -0.88 & -0.47 & 0.00 & -0.81 & -0.46 & 0.01 \\
JLP2-B & 0.24 & -0.23 & -0.72 & -0.45 & -0.90 & -0.54 & 0.00 & -0.83 & -0.50 & -0.44 \\
JLP2-C & -0.06 & -0.04 & -0.78 & -0.19 & -0.86 & -0.55 & 0.00 & -0.32 & -0.24 & -0.39 \\
JLP3-A & 0.27 & -0.12 & -0.46 & -0.39 & -0.69 & -0.52 & 0.00 & -0.56 & -0.21 & -0.11 \\
JLP2-B & 0.22 & -0.07 & -0.42 & -0.36 & -0.73 & -0.58 & 0.00 & -0.59 & -0.20 & -0.32 \\
JLP3-C & 0.26 & 0.19 & -0.27 & -0.12 & -0.61 & -0.48 & 0.00 & -0.33 & -0.07 & -0.36 \\
Average-A & 0.31 & -0.21 & -0.58 & -0.37 & -0.79 & -0.46 & 0.00 & -0.70 & -0.34 & 0.26 \\
Average-B & 0.24 & -0.15 & -0.55 & -0.33 & -0.83 & -0.55 & 0.00 & -0.69 & -0.35 & -0.29 \\
Average-C & 0.18 & 0.17 & -0.47 & 0.16 & -0.74 & -0.51 & 0.00 & -0.20 & -0.01 & -0.30 \\
\hline
\end{tabular}

As the weathering resistance of minerals is opposite to the Bowen reaction order, the higher the crystallization temperature of minerals, the lower the stability of minerals. Nepheline and zeolite are sometimes formed in the matrix together with alkali feldspar and/or potassium feldspar. Potassium in basalt is mainly enriched in medium feldspar, potassium feldspar, or biotite. Due to its strong stability, K element fluctuations are relatively low and stable in the weathering process.

Through the calculation of main element mobility, it can be found that $\mathrm{K}_{2} \mathrm{O}$ is the most stable in the study area. Therefore, mass balance calculation can be used in this study.

$$
\tau_{i, j}=\left(C_{j, w} / C_{j, p}\right) /\left(C_{i, w} / C_{i, p}\right)-1
$$

Formula (4) is widely used to evaluate the migration and redistribution of elements during the formation of chemical weathering profiles [43-45]. The element gain and loss in the profile can be described by the change of the ratio of elements to inactive elements relative to the ratio in the parent rock. $C_{j, w}$ and $C_{j, p}$ are the concentrations of a certain element $\mathrm{J}$ in soil and fresh parent rock, respectively. $C_{i, w}$ and $C_{i, p}$ are the most stable 
concentrations of element $\mathrm{I}$ in soil and fresh parent rock $\left(\mathrm{K}_{2} \mathrm{O}\right.$ is selected as element $\mathrm{I}$ in this study). If $\tau_{i, j}<0$, it reflects the migration or net loss of elements in the profile relative to the parent rock; if $\tau_{i, j}>0$, the elements are relatively enriched or net obtained in the profile; if $\tau_{i, j}=0$, the behavior of elements in the profile is relatively stable.

The enriched elements (average enrichment rate) in the parent material layer of the three sections are $\mathrm{SiO}_{2}>\mathrm{Al}_{2} \mathrm{O}_{3}>\mathrm{Fe}_{2} \mathrm{O}_{3}$, while the lost elements (average loss rate) are $\mathrm{CaO}>\mathrm{Na}_{2} \mathrm{O}>\mathrm{MgO}>\mathrm{MnO}>\mathrm{P}_{2} \mathrm{O}_{5}>\mathrm{TiO}_{2}$ (Table 6). The enriched sedimentary layer is $\mathrm{SiO}_{2}$, and the lost elements are $\mathrm{CaO}>\mathrm{P}_{2} \mathrm{O}_{5}>\mathrm{MgO}=\mathrm{Na}_{2} \mathrm{O}>\mathrm{TiO}_{2}>\mathrm{Fe}_{2} \mathrm{O}_{3}>\mathrm{MnO}>\mathrm{Al}_{2} \mathrm{O}_{3}$. In the leaching layer, $\mathrm{SiO}_{2}$ is enriched, and the lost elements are $\mathrm{Cao}>\mathrm{P}_{2} \mathrm{O}_{5}>\mathrm{MgO}>$ $\mathrm{Na}_{2} \mathrm{O}>\mathrm{Fe}_{2} \mathrm{O}_{3}>\mathrm{TiO}_{2}>\mathrm{MnO}>\mathrm{Al}_{2} \mathrm{O}_{3}$.

\subsection{Behavior of the Trace Elements}

Rare earth elements (REE) have special geochemical properties and are generally considered inactive in supergene geological processes. The information of source rocks carried by REE will not be lost, so it is widely used in sediment source tracking. Nevertheless, we believe that rare earth elements are active in the process of chemical weathering and they may be enriched, migrated, and differentiated in the weathering profile. The basic rocks contain a large amount of feldspar and pyroxene, LREE tends to be enriched in feldspar and biotite, while HREE tends to be enriched in amphibole, pyroxene, and garnet.

The content of rare earth elements in basalt weathering products in the study area has obvious inheritance with the parent rock, but the total amount of rare earth elements in weathering products has leaching tendency. The REE pattern of the samples normalized to chondrite values displays a downslope trend (the differentiation of light and heavy REE is obvious; Figure 5), similar to the characteristics of ocean island basalt (OIB). The content of rare earth elements in parent rock samples is $(241 \sim 271) \times 10^{-6}$, with an average of $257 \times 10^{-6} ; \Sigma$ LREE is $(223 \sim 248) \times 10^{-6}$, average $237 \times 10^{-6} ; \Sigma \mathrm{HREE}$ is $(17.6 \sim 22.5) \times 10^{-6}$, with an average of $20.5 \times 10^{-6}$. The content of rare earth elements in weathering products (parent material layer, sedimentary layer and leaching layer) is $(169 \sim 303) \times 10^{-6}$, with an average of $230 \times 10^{-6} ; \Sigma$ LREE is $(153 \sim 280) \times 10^{-6}$, with an average of $211 \times 10^{-6}$; $\Sigma$ HREE value is $(15.89 \sim 23.4) \times 10^{-6}$, with an average of $19.4 \times 10^{-6}$ (Tables 3 and 4). The REE characteristics of weathering products are compared with those of parent rocks, suggesting that they have inheritance properties. LREE/HREE of parent rock is between 11.0 and 12.7, with an average of 11.6; the range of $(\mathrm{La} / \mathrm{Sm})_{\mathrm{N}}$ is between 3.27 and 4.65, and the range of $(\mathrm{La} / \mathrm{Yb})_{\mathrm{N}}$ is between 15.2 and 26.6. LREE/HREE of weathering products is between 8.43 and 14.3, with an average value of 10.9 ; the range of $(\mathrm{La} / \mathrm{Sm})_{\mathrm{N}}$ is between 8.30 and 17.5. The fractionation of LREE and HREE in the parent rock is obvious, but the $(\mathrm{La} / \mathrm{Yb})_{\mathrm{N}}$ gradually decreases with the strengthening of weathering, and the fractionation degree of LREE and HREE decreases. The $\delta \mathrm{Eu}$ of the parent rock is between 0.93 and 1.05, with an average value of 1.0. There is no Eu anomaly, indicating that plagioclase did not undergo obvious fractional crystallization during magmatic evolution. The $\delta \mathrm{Eu}$ of Weathering products is between 0.56 and 0.93 , with an average value of 0.80 . There is an obvious negative anomaly in Eu. Under reduction conditions, Eu mainly exists in the form of $\mathrm{Eu}^{2+}$, which leads to Eu showing different geochemical behavior from other trivalent rare earth elements. In the geological and geochemical process, uranium is separated from other rare earth elements to form positive or negative uranium anomalies. The formation of partially reduced acidic environment at the redox interface after basalt weathering may be the main cause of Eu negative anomaly [46].

Large ion lithophile elements (LILE, $\mathrm{Ba}, \mathrm{Sr}, \mathrm{Rb}, \mathrm{K}$ ) can form independent minerals and are soluble in water. Their chemical properties are active and easy to move after weathering. At the initial stage of weathering, $\mathrm{Ba}$ and $\mathrm{Sr}$ in the study area are largely lost from the parent rock to the parent metal layer. With the deepening of weathering, their contents are gradually stable. The content of Ba in the parent rock is 2.44 times the background value; the content of leaching layer is 1.52 times of the background value; and $\mathrm{Rb}$ is enriched with weathering (Figure 6). $\mathrm{K}$ is most stable during weathering (Figure 3). 


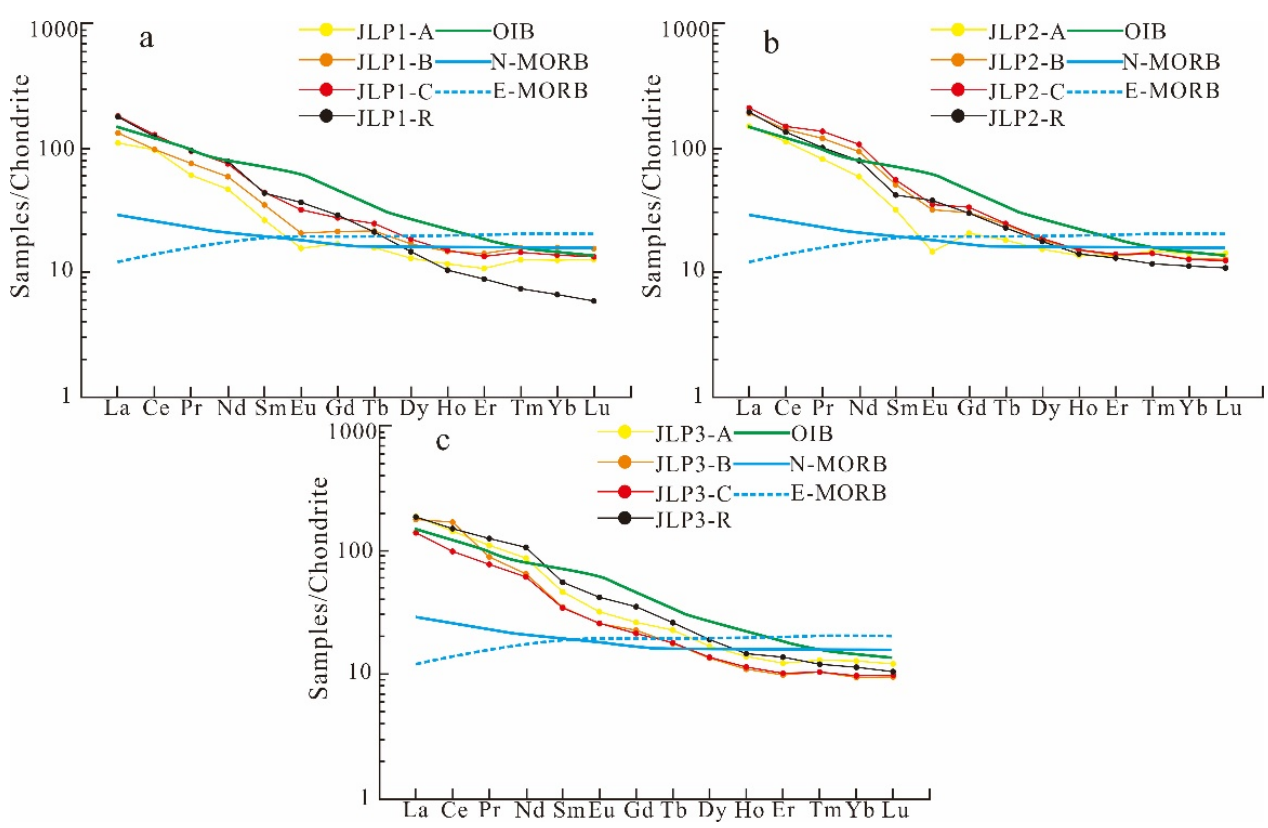

Figure 5. Chondrite normalized distribution model of the REE in the soil profile. Chondrite, OIB, E-MORB, and N-MORB reference values after [47]. Panel (a) is the chondrite normalized distribution model of the REE in soil profile 1. Panel (b) is the chondrite normalized distribution model of the REE in soil profile 2. Panel (c) is the chondrite normalized distribution model of the REE in soil profile 3.
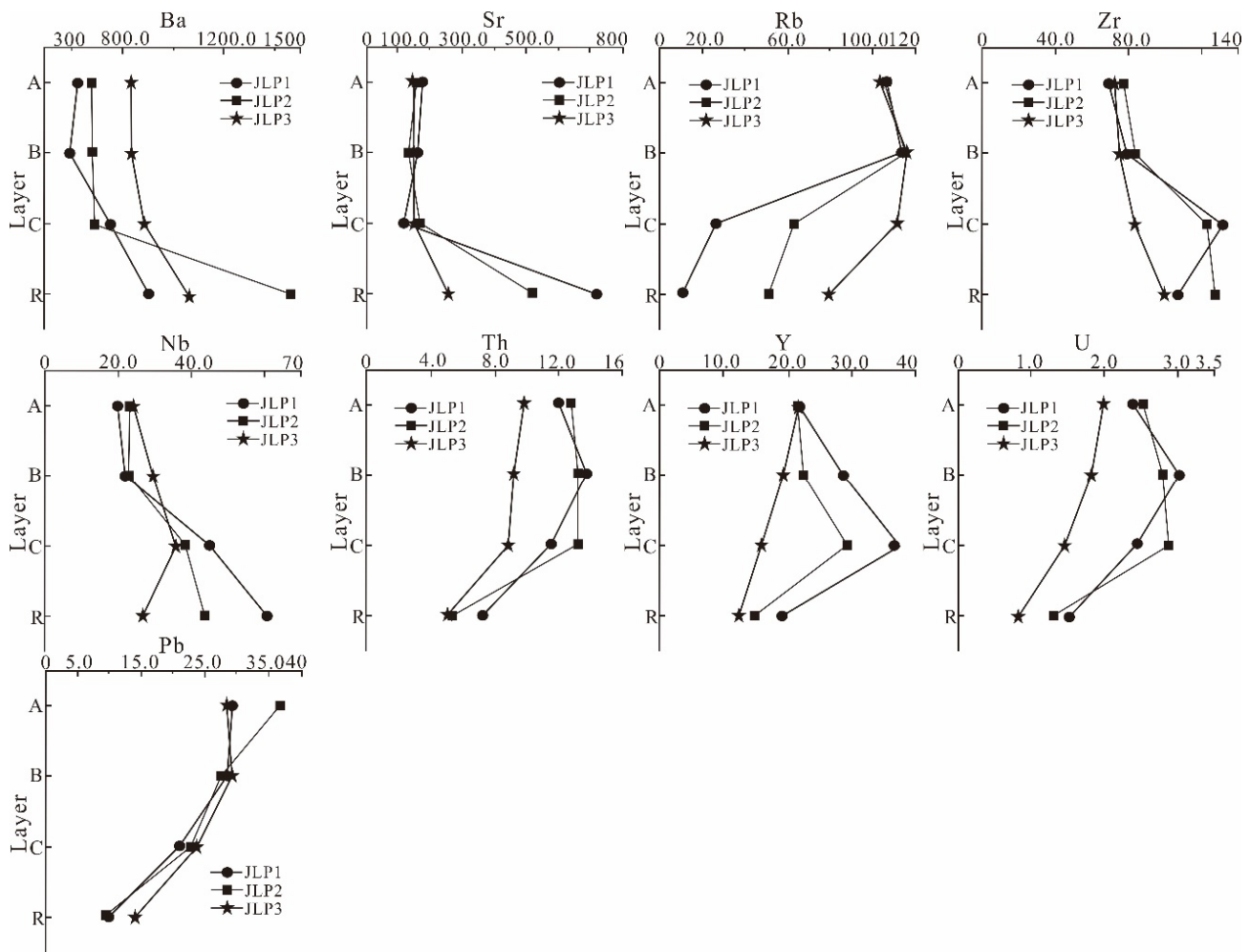

Figure 6. Changes of the trace elements in the soil profile.

High field strength elements (HFSE, $\mathrm{Zr}, \mathrm{Nb}, \mathrm{Th}, \mathrm{Y}, \mathrm{U}$ ) generally have stable chemical properties, high electricity price, ion field strength, and small radius and are generally immobile during geological processes such as metamorphism and different types of alteration, including weathering. Therefore, they are usually used to restore the original properties of 
rocks after later changes. During weathering, five high field strength elements in the study area show different behaviors. $\mathrm{Zr}$ and $\mathrm{Nb}$ are leached; the average movement of $\mathrm{Zr}$ is the smallest; all tested high field strength elements are relatively stable, while Th, Y, and $\mathrm{U}$ are slightly enriched, among which the average movements of Th and $U$ are the largest and most unstable among all tested high field strength elements (Figure 7).

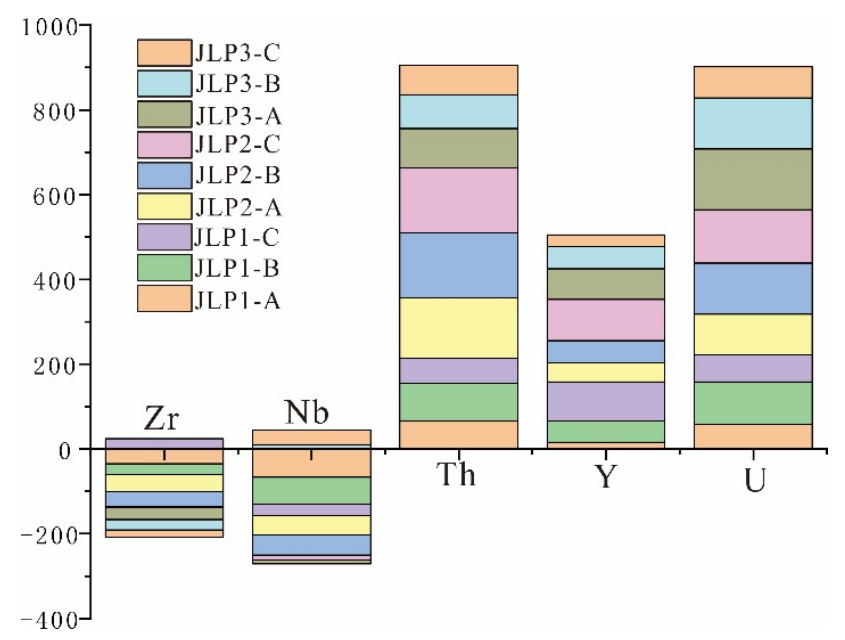

Figure 7. The HFSE stacking diagram.

In this study, there are differences in the concentrations of $\mathrm{SiO}_{2}$ between the parent rocks of these three profiles and basalt. However, the characteristics of trace elements of parent rocks from these profiles and different generations of basalts from the Changbai mountain area are comparable on the spider map (Figure 8). In terms of LILE, both of them are enriched in $\mathrm{Ba}$ and $\mathrm{Sr}$, but depleted in $\mathrm{Rb}$ and $\mathrm{K}$. With regard to HFSE, they are enriched in $\mathrm{Nb}$, while depleted in $\mathrm{U}$ and $\mathrm{Y}$. The characteristics of trace elements support that the parent rocks belong to basalt.

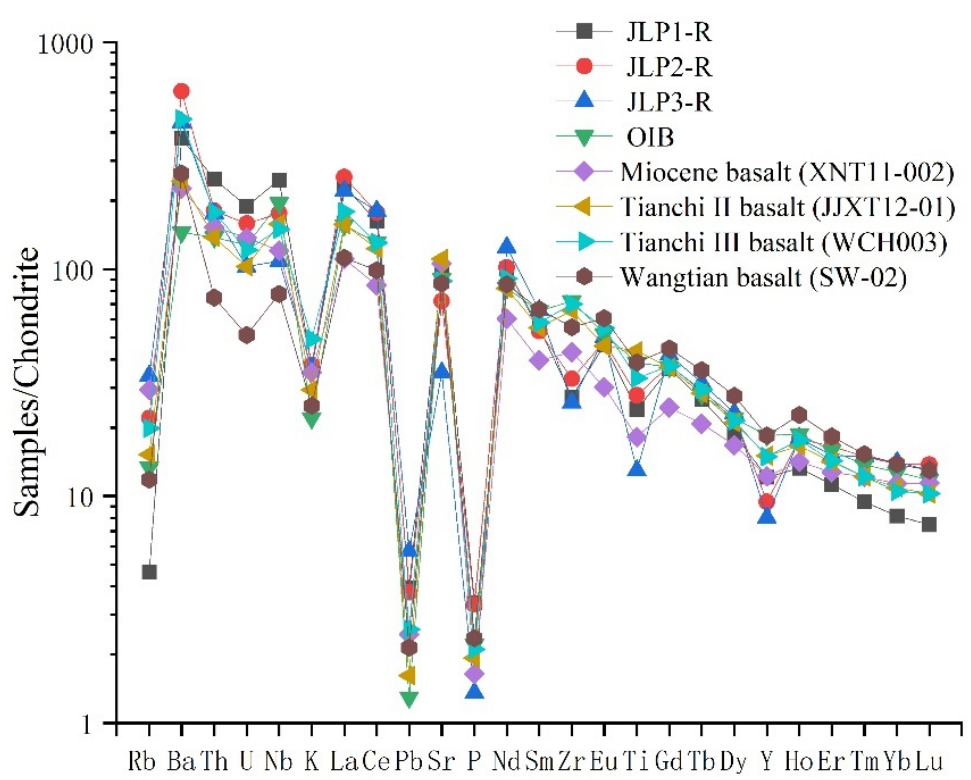

Figure 8. Trace element spider diagram. Chondrite and OIB reference values after [48]. XNT11-002, JJXT12-01, WCH003, and SW-02 reference values after [48].

\section{Conclusions}

The weathering of basalt in Changbai Mountain belongs to moderate weathering under warm and humid climate and forming silica rich soil in the leaching layer. In the 
weathering process, the enrichment rate of $\mathrm{SiO}_{2}$ is the highest, the leaching loss of $\mathrm{CaO}$ is the most serious, and $\mathrm{K}_{2} \mathrm{O}$ is the most stable.

The distribution of the rare earth elements (REE) in the weathering products, normalized to chondrite values, closely recalls that of an OIB-type basalt, with an evident fractionation of LREE with respect to HREE. Such a feature is therefore referable to the fresh parent volcanic rock, which is thought to be an alkaline basalt. Nevertheless, some degree of leaching has occurred during weathering processes in the order of LREE > HREE. Therefore, LREE and HREE fractionation decreased with the increase in weathering degree.

Large ion lithophile elements (LILE), such as $\mathrm{Ba}, \mathrm{Sr}$, and $\mathrm{Rb}$, are very mobile in the weathering process, having been either enriched or leached with respect to the original volcanic rock distribution.

High field strength elements (HFSE), such as $\mathrm{Zr}, \mathrm{Nb}, \mathrm{Th}, \mathrm{Y}$, and $\mathrm{U}$, although much less mobile than LILE, display a different mobility degree during the weathering processes, with $\mathrm{Zr}$ and $\mathrm{Nb}$ being generally more stable than $\mathrm{Th}$ and $\mathrm{U}$.

Author Contributions: Conceptualization, Y.H. and L.H.; software, W.Z.; validation, X.C., Y.Y. and Y.F.; writing — original draft preparation, T.L.; writing—review and editing, J.L. and T.L.; funding acquisition, J.L. All authors have read and agreed to the published version of the manuscript.

Funding: This research was funded by Deep-penetrating Geochemistry Project funded by the State Key Research and Development Program (2016YFC0600606) and Agricultural Geology Projects of China Geological Survey (12120105111208).

Institutional Review Board Statement: Not applicable.

Informed Consent Statement: Not applicable.

Data Availability Statement: The data presented in this study are available on request from the corresponding author.

Acknowledgments: The authors want to express gratitude to the China Geological Survey.

Conflicts of Interest: The authors declare no conflict of interest.

\section{References}

1. Babechuk, M.G.; Widdowson, M.; Kamber, B.S. Quantifying chemical weathering intensity and trace element release from two contrasting basalt profiles, Deccan Traps, India. Chem. Geol. 2014, 363, 56-75. [CrossRef]

2. Jianwu, L.I.; Zhang, G.; Gong, Z. Mobilization and redistribution of elements in soils developed from extreme weathering basalt on Hainan Island. Chin. J. Geochem. 2014, 33, 262-271.

3. Cheng, G.; Liu, Y.; Long, H.; Tao, C.; Ning, Y. A preliminary study on ore-forming environments of Xianglushan-type iron deposit and the weathering mineralization of emeishan basalt in Guizhou Province, China. Acta Geochim. 2017, 36, 556-565. [CrossRef]

4. Ma, J.L.; Wei, G.J.; Xu, Y.G.; Long, W.G. Behavior of major and trace elements in an extreme weathering profile on basalt in Hainan Island, South China. Geochim. Cosmochim. Acta 2006, 70, A379. [CrossRef]

5. Liu, J.H.; Zhou, L.; Algeo, T.J.; Wang, X.; Chen, M.L. Molybdenum isotopic behavior during intense weathering of basalt on Hainan Island, South China. Geochim. Cosmochim. Acta 2020, 287, 180-204. [CrossRef]

6. Mendoza-Grimón, V.; Hernández-Moreno, J.; Martín, J.; Fernández-Vera, J.; Palacios-Díaz, M. Trace and major element associations in basaltic ash soils of El Hierro Island. J. Geochem. Explor. 2014, 147, 277-282. [CrossRef]

7. Kabatapendias, A. Trace Elements in Soils and Plants, 3rd ed.; CRC Press: Boca Raton, FL, USA, 2000; Volume 42, p. 297.

8. Mikkonen, H.G.; Robert, V.D.G.; Clarke, B.O.; Dasika, R.; Wallis, C.J.; Reichman, S.M. Geochemical indices and regression tree models for estimation of ambient background concentrations of copper, chromium, nickel and zinc in soil. Chemosphere 2018, 210, 193-203. [CrossRef]

9. Bradl, H.B. Chapter 1 Sources and origins of heavy metals. In Heavy Metals in the Environment: Origin, Interaction and Remediation, 1st ed.; Bradl, H.B., Ed.; Elsevier: Amsterdam, The Netherlands, 2005; Volume 6, pp. 1-27.

10. Braun, J.J.; Descloitres, M.; Riotte, J.; Fleury, S.; Barbiéro, L.; Boeglin, J.L.; Violette, A.; Lacarce, E.; Ruiz, L.; Sekhar, M. Regolith mass balance inferred from combined mineralogical, geochemical and geophysical studies: Mule Hole gneissic watershed, South India. Geochim. Cosmochim. Acta 2009, 73, 935-961. [CrossRef]

11. Das, A.; Krishnaswami, S. Elemental geochemistry of river sediments from the Deccan Traps, India: Implications to sources of elements and their mobility during basalt-water interaction. Chem. Geol. 2007, 242, 232-254. [CrossRef]

12. Duzgorenaydin, N.; Aydin, A.; Malpas, J. Re-assessment of chemical weathering indices: Case study on pyroclastic rocks of Hong Kong. Eng. Geol. 2002, 63, 99-119. [CrossRef] 
13. Gong, Q.; Deng, J.; Wang, C.; Wang, Z.; Zhou, L. Element behaviors due to rock weathering and its implication to geochemical anomaly recognition: A case study on Linglong biotite granite in Jiaodong peninsula, China. J. Geochem. Explor. 2013, 128, 14-24. [CrossRef]

14. Gong, Q.; Deng, J.; Yang, L.; Zhang, J.; Wang, Q.; Zhang, G. Behavior of major and trace elements during weathering of sericite-quartz schist. J. Asian Earth Sci. 2011, 42, 1-13. [CrossRef]

15. Gu, J.; Huang, Z.L.; Jin, Z.G.; Xiang, X.L. Immobile elements geochemistry and mass balance calculate of bauxite in WuchuanZheng'an—Daozhen Area, Northern Guizhou Province, China. Acta Mineral. Sin. 2011, 31, 94-102.

16. Markovics, H.W.N. Weathering of granodioritic crust, long-term storage of elements in weathering profiles, and petrogenesis of siliciclastic sediments. Geochim. Cosmochim. Acta 1997, 61, 1653-1670.

17. Panahi, A.; Young, G.M.; Rainbird, R.H. Behavior of major and trace elements (including REE) during Paleoproterozoic pedogenesis and diagenetic alteration of an Archean granite near Ville Marie, Québec, Canada. Geochim. Cosmochim. Acta 2000, 64, 2199-2220. [CrossRef]

18. Pedersen, F.; Bjørnestad, E.; Andersen, H.V.; Kjølholt, J.; Poll, C. Characterization of sediments from Copenhagen Harbour by use of biotests. Water Sci. Technol. 1998, 37, 233-240. [CrossRef]

19. Sayit, K. Immobile trace element systematics of oceanic island basalts: The role of oceanic lithosphere in creating the geochemical diversity. Ofioliti 2013, 38, 101-120.

20. Yan, T.; Wu, X.; Quan, Y.; Gong, Q.; Li, X.; Wang, P.; Li, R. Heredity, inheritance and similarity of element behaviors among parent rocks and their weathered products: A geochemical lithogene. Geoence 2018, 32, 453-467.

21. Qian, C.; Cui, T.R.; Tang, Z.; Jinag, B.; Zhang, C.; Lu, L.; Hui, J.; Wang, Y. Characteristic and genesis discussion of Bi-model volcanic activity during Manjiang Stage, Tianchi Volcano. Geol. Rev. 2017, 63, 287-288.

22. Fan, Q.C.; Sui, J.L.; Wang, T.H.; Li, N.; Sun, Q. Eruption history and magma evolution of the trachybasalt in the Tianchivolcano, Changbaishan. Acta Petrol. Sin. 2006, 6, 3-11.

23. Fan, Q.C.; Sui, J.L.; Wang, T.H.; Li, N.; Sun, Q. History of volcanic activity, magma evolution and eruptive mechanisms of the changbai volcanic province. Geol. J. China Univ. 2007, 13, 175-190.

24. Liu, J.Q.; Chen, S.S.; Guo, W.F.; Sun, C.Q.; Zhang, M.L.; Guo, Z.F. Research advances in the Mt. Changbai Volcano. Bull. Mineral. Petrol. Geochem. 2016, 34, 710-723.

25. Li, J.Y. Permian geodynamic setting of Northeast China and adjacent regions: Closure of the Paleo-Asian Ocean and subduction of the Paleo-Pacific Plate. J. Asian Earth Sci. 2006, 26, 207-224. [CrossRef]

26. Tang, J.; Xu, W.-L.; Wang, F.; Wang, W.; Xu, M.-J.; Zhang, Y.-H. Geochronology and geochemistry of neoproterozoic magmatism in the Erguna Massif, NE China: Petrogenesis and implications for the breakup of the rodinia supercontinent. Precambrian Res. 2013, 224, 597-611. [CrossRef]

27. Feng, T.; Tang, D. Petrogenesis of the cenozoic volcanic rocks in the changbaishan region. Acta Petrol. Sin. 1989, 2, 156-186.

28. Cui, Z.; Liu, J.Q. The historical records about the extensive eruptions of the Tianchi Volcano in Changbai Mountains during AD 1014-1019. Geol. Rev. 2006, 5, 624-627.

29. Wu, F.Y.; Sun, D.Y.; Ge, W.C.; Zhang, Y.B.; Grant, M.L.; Wilde, S.A.; Jahn, B.M. Geochronology of the phanerozoic granitoids in northeastern China. J. Asian Earth Sci. 2011, 41, 1-30. [CrossRef]

30. Chen, J.; Wei, F.; Zheng, C.; Wu, Y.; Adriano, D.C. Background concentrations of elements in soils of China. Water Air Soil Pollut. 1991, 57-58, 699. [CrossRef]

31. Teng, Y.; Jin, W.; Lu, S.; Wang, Y.; Jiao, X.; Song, L. Soil and soil environmental quality monitoring in China: A review. Environ. Int. 2014, 69, 177-199. [CrossRef] [PubMed]

32. Aristizábal, E.; Roser, B.; Yokota, S. Tropical chemical weathering of hillslope deposits and bedrock source in the Aburrá Valley, northern Colombian Andes. Eng. Geol. 2005, 81, 389-406. [CrossRef]

33. Borges, J.; Huh, Y. Petrography and chemistry of the bed sediments of the Red River in China and Vietnam: Provenance and chemical weathering. Sediment. Geol. 2007, 194, 155-168. [CrossRef]

34. Ohta, T.; Arai, H. Statistical empirical index of chemical weathering in igneous rocks: A new tool for evaluating the degree of weathering. Chem. Geol. 2007, 240, 280-297. [CrossRef]

35. Riebe, C.S.; Kirchner, J.W.; Finkel, R.C. Long-term rates of chemical weathering and physical erosion from cosmogenic nuclides and geochemical mass balance. Geochim. Cosmochim. Acta 2003, 67, 4411-4427. [CrossRef]

36. Parker, A. An index of weathering for silicate rocks. Geol. Mag. 1970, 107, 501-504. [CrossRef]

37. Nesbitt, H.W.; Young, G.M. Early proterozoic climates and plate motions inferred from major element chemistry of lutites. Nature 1982, 299, 715-717. [CrossRef]

38. Harnois, L. The CIW index: A new chemical index of weathering. Sediment. Geol. 1988, 55, 319-322. [CrossRef]

39. Colman, S.M. Chemical Weathering of Basalts and Andesites: Evidence from Weathering Rinds; U.S. G.P.O.: Washington, DC, USA, 1982.

40. Fedo, C.M.; Wayne Nesbitt, H.; Young, G.M. Unraveling the effects of potassium metasomatism in sedimentary rocks and paleosols, with implications for paleoweathering conditions and provenance. Geology 1995, 23, 921-924. [CrossRef]

41. Mclennan, S.M. 100th anniversary symposium: Evolution of the Earth's surface weathering and global denudation. J. Geol. 1993, 101, 295-303. [CrossRef] 
42. Feng, Z.; Wang, S.; Liu, X.; Luo, W. Impact of acid-insoluble residua of carbonate rocks on developing intensities of their weathering crusts. Acta Geol. Sin. 2009, 83, 885-893.

43. Babechuk, M.G.; Widdowson, M.; Murphy, M.; Kamber, B.S. A combined Y/Ho, high field strength element (HFSE) and Nd isotope perspective on basalt weathering, Deccan Traps, India. Chem. Geol. 2015, 396, 25-41. [CrossRef]

44. Kurtz, A.; Derry, L.A.; Chadwick, O.A.; Alfano, M.J. Refractory element mobility in volcanic soils. Geology 2000, 28, $279-282$. [CrossRef]

45. Nesbitt, H.W.; Markovics, G.; Price, R.C. Chemical processes affecting alkalis and alkaline earths during continental weathering. Geochim. Cosmochim. Acta 1980, 44, 1659-1666. [CrossRef]

46. Zhao, P.; Li, A.M.; Li, S.T.; Yang, C.F.; Zhao, F.Y.; Yan, C.J.; Wang, Z.P.; Chen, J.; Yang, G. The REE geochemical characteristics of the basalt weathering crust in the northwestern Guizhou. Acta Mineral. Sin. 2019, 39, 122-131.

47. Sun, S.S.; Mcdonough, W.F. Chemical and isotopic systematics of ocean basalts: Implications for mantle composition and processes. In Magmatism in the Ocean Basins; Geological Society London Special Publications: London, UK, 1989; Volume 423, pp. 13-345.

48. Guo, W.; Liu, J.; Guo, Z. Temporal variations and petrogenetic implications in Changbai basaltic rocks since the Pliocene. Acta Petrol. Sin. 2014, 30, 3595-3611. 